\title{
A Mulher Maravilha e o poder do amor
}

Wonder Woman and the Power of Love

Arquivo enviado em

04/05/201

e aprovado em

18/08/2019.

V. $9-$ N. $18-2019$

*Doutoranda em Ciências da Religião no PPGCR da

PUC Minas, como bolsista

FAPEMIG, sob orientação do Prof. Dr. Flávio Senra.

Mestra em Ciências da

Religião no PPGCR da PUC

Minas 2018, como bolsista

CAPES. 2018, sob orientação

do Prof. Dr. Flávio Senra.

Bacharel em Direito pela PUC

Minas 2008. Especialista em

Direito do Trabalho. Bacharel

em teologia pelo Centro

Universitário Izabela Hendrix 2018. Membro do grupo de pesquisa Religião e Cultura do PPGCR da PUC Minas.

\section{Claudia Danielle de Andrade Ritz*}

\section{Resumo}

Este artigo versa sobre o HQ1 Edição de Verão e o filme Mulher Maravilha estreado em 2017 pela DC Comics. A história se iniciou com gibis, até que alcançasse as telas. Nosso objetivo nesse artigo será discutir e apresentar a origem de Diana e das amazonas, conforme $\mathrm{HQ1}$ e algumas cenas do filme da DC Comics 2017, numa perspectiva Teoliterária, unindo Teologia e Literatura a partir das Histórias em Quadrinhos (HQ). Trabalharemos nesse artigo sobre a Mulher Maravilha a partir de três eixos: Uma heroína que promove a justiça; Marte/Ares com sua obsessão pela guerra e o amor ao poder, e, a Mulher Maravilha que escolhe o poder do amor. Utilizaremos como metodologia referencial teórico.

\section{Palavras-chave: Mulher Maravilha.} Justiça. Guerra. Poder. Amor.

\section{Abstract}

This article is about the HQ1 Summer Edition and the film Wonder Woman launched in 2017 by DC Comics. The story began with comic books, was made a movie. Our objective in this article is to discuss the origin of Diana and the Amazons, according to HQ1 and some scenes from the DC Comics 2017 movie, in a Theoliterary perspective, joining Theology and Literature from Comic Books. We will work on this article from three axes: 
the heroine who promotes justice; Mars / Ares and the obsession with war and the love of power, and Wonder Woman who chooses the power of love. We will use as theoretical reference methodology.

Keywords: Wonder Woman. Justice. War. Power. Love.

\section{Introdução}

To Be Human [...]

Even when it gets too much

I'm not ready to give up

To be human is to love

Even when it gets too much

There's no reason to give up

Don't give up

Feat Labirinth (2017) $)^{1}$

esse artigo trabalharemos a história em quadrinhos (HQs) da Mulher Maravilha que remonta à mitologia greco-romana e foi criada na década de 1940 por William Moulton Marston $^{2}$, sob pseudônimo de Charles Moulton. No artigo publicado pela Family Circle com o título de Don't Laugh at the Comics, William Moulton Marston descrevia o potencial educacional que percebia nas histórias em quadrinhos ${ }^{3}$ e por isso, merecia especial atenção do autor, que era também pesquisador e cientista.

Conforme Caldas (2017, p. 70) "as HQs constituem-se em uma

1. Ser humano - Ser humano é amar. Mesmo quando for demais. Não estou pronta para desistir. Ser humano é amar. Mesmo quando for demais. Não estou pronta para desistir. Não desista. Tradução nossa.

2. O Dr. William Moulton Marston era psicólogo formado em Harvard, doutorado em direito e Ph.D. em psicologia. Além de ator da mulher maravilha, foi também o criador do primeiro protótipo do polígrafo, cuja função é detectar se a pessoa está falando a verdade. Talvez por isso, tenhamos no HQ o laço da verdade.

3. Foto da reportagem disponível em: http://cbldf.org/2012/10/tales-from-the-code-whatever-happened-to-the-amazing-amazon-wonder-woman-bound-by-censorship/. Acesso em: 02 maio. 2019. 
das mais difundidas formas de arte sequencial da contemporaneidade." Trata-se de uma arte cuja linguagem se aproxima da realidade do cotidiano e é permeada por questões sociais pulsantes, por isso, educativas e críticas. Viana (2005, p. 61), afirma que "o processo de criação da superaventura é um processo consciente, no qual o criador envia uma mensagem na maioria das vezes axiológica." Muitos artistas ao criarem os personagens, se inspiravam em mitos e culturas diversas, assim como em questões emergentes na sociedade, como ocorreu com William Moulton Marston.

Pensando na mensagem que é passada por meio da superaventura, destacamos como importante o processo interpretativo. Caldas (2017, p. 74) corrobora que "outro ponto que há de ser lembrado no processo interpretativo das narrativas ficcionais é quanto ao papel do leitor no círculo hermenêutico. " Por isso, ao trabalharmos a arte em HQ e filme, e, em perspectiva de análise interpretativa com imbricamento teológico, a tarefa se torna teoliterária.

Pode-se dizer que esse gibi fez emergir não apenas uma heroína num contexto de super-heróis, mas mostrou ao mundo uma mulher imponderada que não é a garota do super-herói, uma voz crítica em meio a uma sociedade hegemonicamente androcêntrica. Ademais, a história aborda questões de preceitos éticos, violência, guerra, verdade, justiça, morte e amor, por exemplo.

No HQ1, havia uma disputa entre Marte/Ares e Afrodite. O planeta Terra era disputado por estes deuses que representavam a face da guerra e a do amor respectivamente. A imagem abaixo retrata o diálogo entre os deuses e o planeta como pano de fundo. A dinâmica se desenvolverá a partir desse impasse mitológico que se desenrolará e alcançará os humanos. 


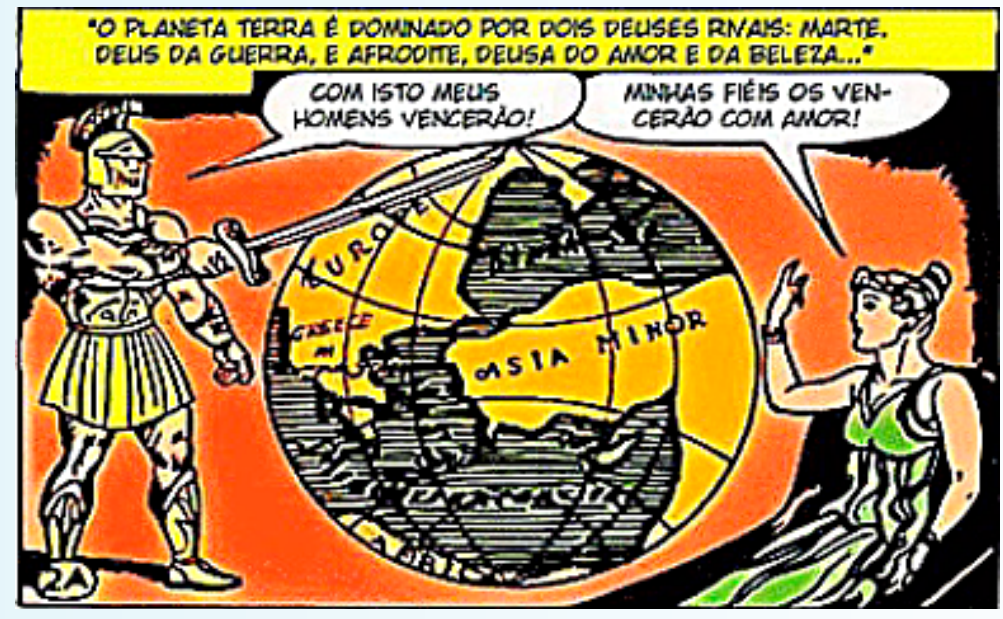

Imagem I: HQI Disputa entre Marte e Afrodite

Fonte: DC Comics- Edição de verão

Sob essa égide, este artigo compreenderá a Mulher Maravilha como heroína que promove a justiça, Marte (HQ1)/Ares (filme 2017) como um deus emantado pela guerra e "pelo amor ao poder" via violência, e, por fim, a Mulher Maravilha e sua escolha pelo "poder do amor". A metodologia utilizada será referencial teórico, e como fontes contamos com o HQ1 Edição de verão e o filme lançado pela DC Comics em 2017, com o título Mulher Maravilha, estrelado pela atriz israelense Gal Gadot.

\section{Mulher Maravilha}

Afirma o HQ1 que a história da Mulher Maravilha é "a história de uma raça, pois remonta a uma época na qual as mulheres belas eram mais fortes que os homens, dominavam e adoravam a deusa do amor e beleza - Afrodite. O HQ1 Edição de Verão da Mulher Maravilha, destaca em sua capa, que a edição apresenta dez aventuras completas nunca antes publicadas, com dados importantes sobre a origem de Diana. 
Na ilustração a Mulher Maravilha surge como uma princesa amazona cavalgando em seu cavalo branco - a cor simbólica da paz, com o laço da verdade - em analogia à justiça, num cenário de guerra repleto de homens armados com seus revolveres e canhões. A ilustração pode ser interpretada como uma alusão da Mulher Maravilha em sua luta pela paz. Ressaltamos que o contexto histórico de guerras assolava sobretudo a Europa e os EUA no passado, considerando a história do $\mathrm{HQ}$ como sendo da década de 1940.

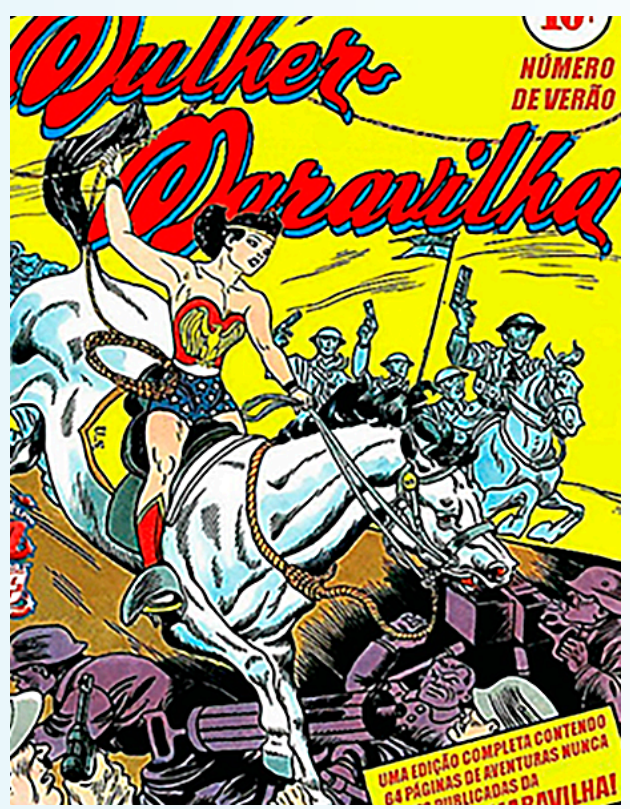

Imagem 2: Capa HQI de Charles Moulton ${ }^{4}$ Fonte: DC Comics- Edição de verão

A heroína tem origem que remonta à mitologia greco-romana. Por isso, traz em suas histórias vários conteúdos próprios daquela cultura, entremeados com a contemporaneidade, numa conexão cultural e histórica muito interessante e provocativa. Esse traço cultural mitológico é evidenciado nas interjeições típicas da Heroína

4. Pseudônimo de William Moulton Marston. 
nos HQs como a famosa expressão "grande Hera!" ou "pela lança de Atena" - referência a duas deusas Gregas. De acordo com o HQ1, a Mulher Maravilha reúne características do panteão greco-romano, expresso também em seu nome - Diana, uma referência à deusa romana da lua e da caça, detentora de grande força física, nome que teria sido escolhido pela própria deusa Afrodite.

Segundo o HQ1, a beleza ${ }^{5}$ da princesa Diana teria sido herdada da própria deusa Afrodite ${ }^{6}$, a sabedoria da deusa Atenas ${ }^{7}$, a força de Hércules, e a velocidade de Mercúrio . "Bela como Afrodite, sábia como Atena, forte como Hércules e rápida como Mercúrio/ Hermes", descrevia os primeiros gibis da heroína.

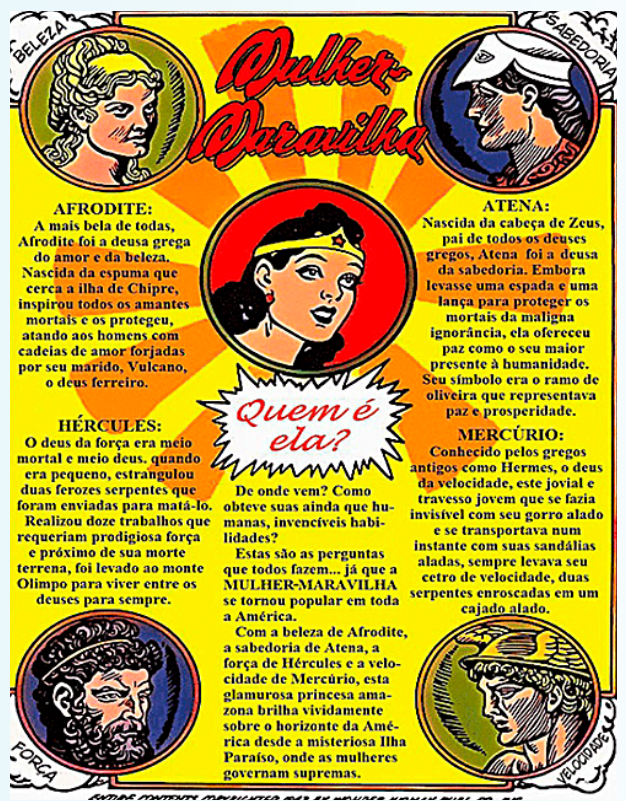

Imagem 3: HQI: Quem é ela?

Fonte: DC Comics- Edição de verão

5. Dados constantes na introdução do HQ 1, série de verão.

6. Deusa grega da beleza, da sexualidade e do amor.

7. Deusa grega da civilização, da sabedoria, da estratégia em batalha, das artes, da justiça e da habilidade.

8. Deus da mitologia romana, equivalente a Hermes na mitologia grega. É um mensageiro, veloz, deus da venda, lucro e comércio. 
O filme de 2017, atribui adjetivos parecidos num dos cartazes disponibilizados - poder, elegância, sabedoria, maravilhosa.

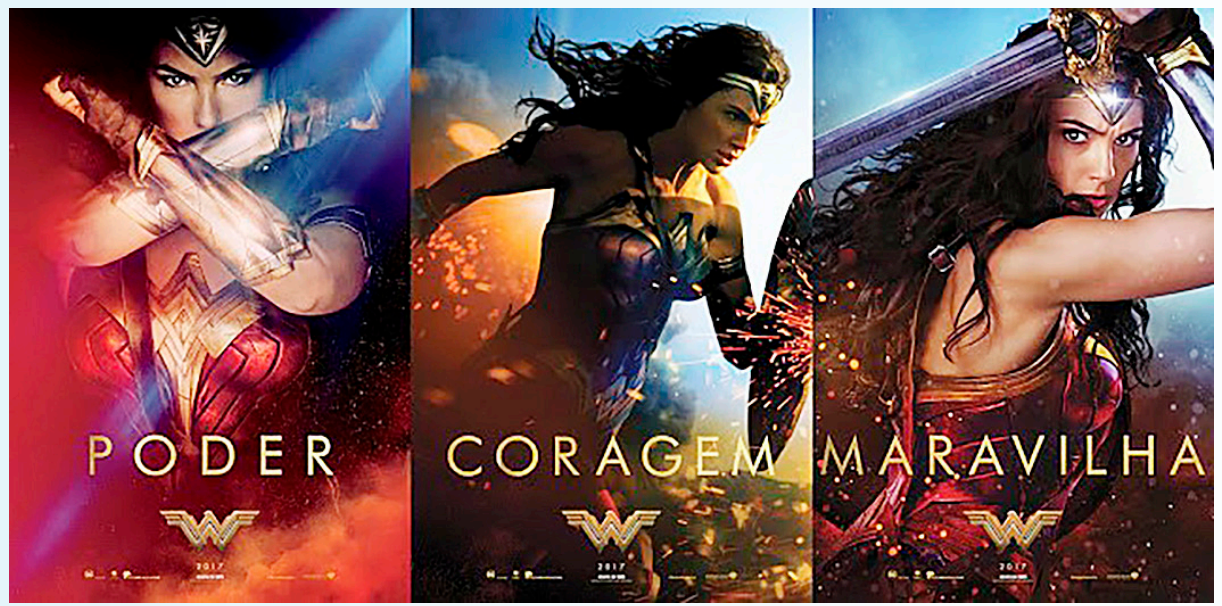

Imagem 4: Mulher Maravilha: Poder, coragem, maravilha Fonte: DC Comics - Filme 2017

Partindo do contexto da mitologia, Diana remete tanto ao mito, quanto à força do mito na sociedade, Reblin (2012). No HQ1, o planeta Terra tinha sido disputado por dois deuses rivais - Marte deus da guerra, que no filme de 2017 é conhecido pela versão grega Ares, e a deusa do amor e da beleza Afrodite. Marte empunha a espada - conotando instrumento de violência e morte - afirmando que os homens vencerão pela força e guerra. Afrodite contradiz dizendo que as suas fiéis vencerão pelo poder do amor. Há polarizações entre violência e amor, guerra e paz, morte e vida.

No HQ1, o debate revela também uma aparente disputa entre gêneros, na qual, Ares sai vitorioso e vende as mulheres como escravas, com valoração financeira menor que o custo de cabras. Diante desse cenário, Afrodite molda com suas mãos mulheres mais fortes que os homens, ou seja, uma segunda geração feminina. Nesse aspecto, salientamos a criação humana descrita na 
bíblia (Gn 2.7), na qual o homem teria sido moldado por Deus da terra, e, a mulher, derivada da carne e ossos do homem Adão ( $\mathrm{Gn}$ 2.22). Então, pela narrativa, a origem está no barro, assim como do fim humano, que é retornar ao barro (Gn 3.19). O início e fim se encontram na mesma matéria - terra. Porque, da mesma maneira que em nós há vida, em nós reside a morte (2 Co 4.12) e o mesmo elemento constitutivo será o elemento último. Assim, a origem e fim da matéria se encontram e retornam ao planeta Terra.

Afrodite, concede o poder distintivo do amor às mulheres que denomina amazonas. A deusa cria Hipólita e a faz rainha das amazonas, num reino diferente e concede a Hipólita seu próprio cinturão mágico - um adereço divino, que deve ser usado pela rainha. Esse cinturão tornaria as amazonas invencíveis. A cidade que as amazonas originalmente construíram é denominada no HQ1 de Amazônia, um local belo, quase que como a terra prometida que mana leite e mel (Nm.13:27), uma terra maravilhosa, para mulheres maravilhosas.

Não obstante, Marte não desiste e se une a Hércules (deus da força física) que é convencido a lutar contra as amazonas. Na luta, Hipólita usando o cinturão de Afrodite vence Hércules, que recorre à traição, usando a proposta de paz como argumento para um "drink", quando na verdade pensava em cortejar a rainha. Tal atitude era uma 'estratagema' tida no HQ1 como feminina, e usada por Hércules contra as mulheres. A estratégia de Hércules progride e em posse do cinturão mágico, domina e acorrenta as amazonas. Após o golpe de sedução sofrido, Hipólita clama pela misericórdia de Afrodite e reconhece seu pecado de desobediência, pois não deveria ter tirado o cinturão, quiçá entregue a Hércules. A deusa do amor socorre suas fiéis, rompe os grilhões e elas se libertam. 
Por causa disso, Afrodite coloca braceletes nas amazonas, para que se lembrem que é tolice se submeter ao domínio dos homens.

Ainda como consequência, as amazonas tiveram que partir da Amazônia e seguir de barco para uma ilha prometida onde teriam novamente paz e segurança, mas não seria permitida a entrada de homens. Esse novo lar é a Ilha do Paraíso, que no filme de 2017 se chama Ilha Themyscira. Já habitando a ilha, a rainha Hipólita, do mesmo modo como fizera a deusa Afrodite anteriormente, teria moldado uma forma humana feminina com suas mãos, porém, uma menina criança. Afrodite, atendendo ao pedido da rainha, concede a dádiva da vida à forma moldada com barro. De tal modo que, sem copulação ou gestação, emerge à vida uma pequena menina, nomeada por Afrodite como Diana - em homenagem à deusa Diana $^{9}$, da caça e da lua. Não uma guerreira, mas uma amazona pacificadora da guerra, pelo poder do amor.
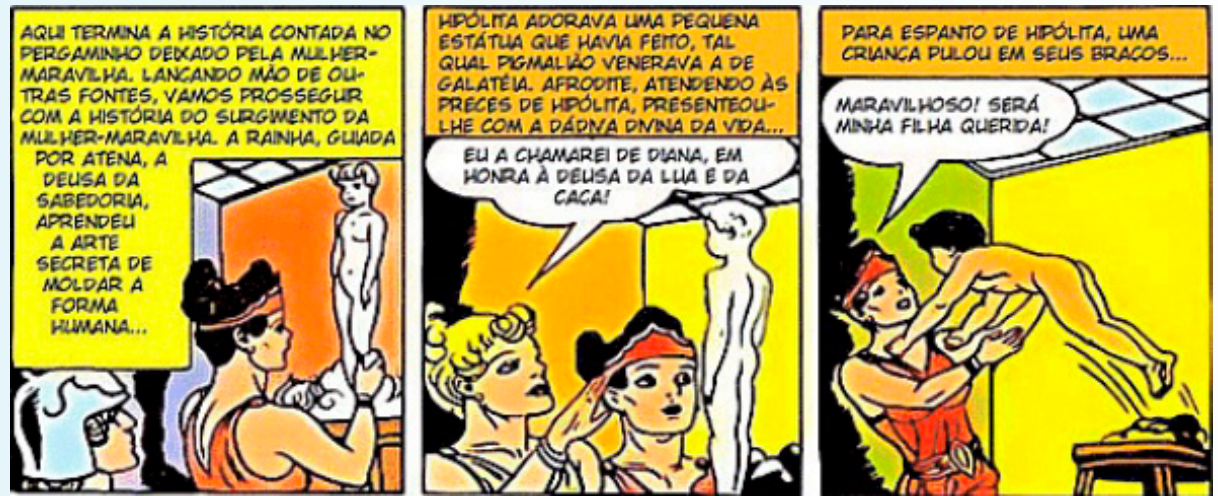

Imagem 5: A origem de Diana

Fonte: DC Comics- número de verão

Aos quinze anos, a princesa Diana recebe os braceletes da submissão no altar de Afrodite e bebe da fonte da eterna juventude, que garantiria não apenas beleza, mas também felicidade en-

9. Na Bíblia há menção à deusa Diana em At. 19.24, 19.27, 19.28, 19.34 e 19.35. 
quanto residisse na ilha, essa era a herança das amazonas. Anos depois, de acordo com o HQ1, Diana passeava junto de sua amiga Mala, quando vê a asa de um avião no mar. As duas se unem e salvam o capitão do serviço de inteligência americana Steve Trevor que estava na cena do acidente. Frente às poucas chances de sobrevivência do ferido, Diana busca exaustivamente aperfeiçoar sua pesquisa de frequência púrpura curativa, que ao ser usada, ressuscita o recém falecido Steve Trevor. No filme (2017), Steve Trevor não falece, e a frequência púrpura não é apresentada.

Em paralelo, no HQ1, Marte debocha de Afrodite, pois o mundo estaria em guerra. Afrodite afirma que enviaria uma amazona para ajudar a América a vencer e encerrar a guerra em curso. Há então, um decreto real para selecionar a amazona mais forte para essa missão. Diana se interessa, porém, Hipólita a proíbe de participar, o que não obedecido pela princesa. Diana, é a competidora número sete, se disfarça, participa e vence. Ao final, sua mãe é surpreendida ao descobrir a identidade da competidora mascarada número sete - Diana. Cumprindo o rito, Hipólita a entrega sua nova roupa e o laço mágico da verdade (que é feito de fios de ouro, tirados do cinturão mágico de Afrodite). A produção do laço teria sido ordem de Afrodite.

No filme (2017), Diana decide partir para a Terra, após Steve Trevor, sob efeito do laço da verdade, contar sobre a guerra em curso. Hipólita discorda das intenções da princesa das amazonas e alega que "a humanidade não a merecia". Não obstante, Diana está decidida e Hipólita respeita a decisão de sua filha. Junto com Steve Trevor, a princesa parte para cumprir o que acredita ser sua missão, qual seja, enfrentar Ares e encerrar a guerra. No HQ1, a saída ilha ocorre no avião invisível e no filme acontece em um barco. 
Em termos teológicos, a mãe Hipólita e sua amada filha Diana, nos lembra em alguma medida a história de Abraão e Isaque, o filho da promessa que segue para o sacrifício - pela humanidade e por Deus, respectivamente. Ao analisar a história de Abraão e Isaque, Kierkegaard pondera:

[...] muitos pais, quando perdem seu filho, acreditaram ficar sem o mais caro tesouro do mundo e privados de toda esperança futura; porém, nenhum foi o filho da promessa no sentido em que Isaque foi para Abraão. (KIERKEGAARD, 2008, p. 17).

Ocorre que, se para Abraão o sacrifício de Isaque, embora sofrido, era devido e justo, pois seria em honra a um Deus justo, provedor e merecedor (Gn. 22), ao contrário, para Hipólita, o sacrifico de Diana era indevido e injusto, pois seria em prol de um povo injusto, cruel e não merecedor. Se Abraão conduz Isaque ao sacrifício em uma montanha em Moriá, Hipólita tenta impedir que Diana saia da ilha. Isaque segue a orientação do seu pai Abraão por acreditar ser aquela sua missão. Diana não segue a orientação de sua mãe, por acreditar que lutar em nome do fim da guerra seja sua missão. Isaque (G. 22.9-10) e Diana, ambos aceitaram sua missão, mesmo que isso corresponda a sacrifícios pessoais. Diana assevera "É o nosso dever sagrado defender o mundo, e é isso que eu vou fazer." Um apurado senso de justiça e alteridade.

\section{A Mulher Maravilha, uma heroína que promove a justiça}

Se tiver de interferir com um sistema acomodado e antiquado para ajudar apenas uma mulher, um homem ou uma criança... Aceito de bom grado as consequências. (DIANA, 2017).

A decisão de Diana em partir para a Terra, traz o imperativo de sair do seu lar e se lançar no desconhecido. Em termos kierke- 
gaardianos, diríamos que Diana deu um salto de fé em prol da humanidade. Um salto de fé é uma decisão do indivíduo, que, movido por sua paixão e convicção se lança no desconhecido. Para Kierkegaard (2008, p. 114): "A fé é a mais elevada paixão de qualquer homem. Talvez existam muitos homens de cada geração que não a atinjam, porém, nenhuma vai além dela." Diana tinha fé na sua missão e no poder do amor. Ela se lançou.

Steve Trevor diante da decisão de Diana de agir para acabar com a guerra, afirma: "Olha, eu adoro seu entusiasmo, mas essa guerra é uma grande bagunça. Não há muito que eu ou você possamos fazer sobre isso. Nós podemos voltar para Londres e tentar achar os homens que possam." Há incredulidade por parte do capitão Trevor. Incredulidade no poder de uma mulher, obviamente oriundo do costume da época, no qual as relações de gênero estabelecidas sequer contemplavam mulheres no comando, na linha de frente ou nas trincheiras de guerra, quiçá, acabando com a guerra. Há também incredulidade na capacidade humana de viver sem conflito. E, por fim, na sua responsabilidade e contribuição pessoal para o fim da guerra. Tais questões são compreendidas e apreendidas por Trevor ao longo do filme de 2017.

Diana (2017) perspicaz, subversiva e corajosa responde: "Eu sou o homem que pode." Nesse diálogo há um rompimento imediato com o poderio masculino, destacando que o poder não está adstrito aos homens, como costumeiramente pensado (BOURDIEU, 2002). Além disso, há um apurado senso de responsabilidade e coragem, e tais preceitos engajam igualmente Trevor na busca pela paz, e na força do amor, não apenas por Diana, mas pelos amigos envolvidos, pelas pessoas. Esta transformação arrebatadora do amor, o fará doar sua vida pela dos demais. 
No filme, ao chegar na Europa, Diana é confrontada com um sistema cultural completamente diferente daquele vigente na ilha de Themyscira. Diana não compreende algumas estruturações sociais, absorvidas pela humanidade local, como um habitus (BOURDIEU, 2017). Diana questiona o sistema vigente, como por exemplo no diálogo com a secretária Etta Candy, no qual evidencia questões de desigualdades de gênero, inclusive na ordem socioeconômica presente nas relações de trabalho.

Etta Candy: Eu sou a secretária do Steve Trevor.

Diana: O que é secretária?

Etta Candy: Eu vou onde ele fala pra eu ir, eu faço o que ele me diz para fazer.

Diana: De onde eu venho, isso é chamado de escravidão.

Etta Candy: Eu gosto dela!

O diálogo conduz a uma reflexão sobre o lugar das mulheres no ambiente profissional e ainda, sobre as relações de trabalho vigentes. Tais constatações que desprivilegiam as mulheres, é uma realidade também na contemporaneidade, como aponta, por exemplo, a estatística de gênero do IBGE (2018) ${ }^{10}$. As mulheres auferem menores salários, e, na política, são minoria. Por isso, o gênero nesse diálogo, pode ser considerado como uma das ferramentas críticas para análise (SCOTT, 1989). Para pensarmos gênero, Joan Scott (1989, p. 20; 2013, p. 02) pondera que é possível pensarmos enquanto "ferramenta crítica, [...] um elemento constitutivo [...] uma pergunta a ser feita na sociedade, [...] uma norma regulamentadora, e [...] uma categoria útil de análise".

Hodiernamente, há questões outras sendo refletidas, mas certamente, o gênero pode ser considerado útil nas análises das

10. IGBE (2018). Disponível em: https://biblioteca.ibge.gov.br/visualizacao/livros/ liv101551_informativo.pdf. Acesso em: 01 maio. 2018. 
relações sociais estabelecidas entre homens e mulheres, que foi abordado quando da criação da HQ1 em 1940 e continua na atualidade com o filme da DC Comics em 2017. A cultura de desigualdade de gênero é percebida por Diana, mas internalizada pelos humanos com certa naturalidade. Sobre esse aspecto, Ritz (2018) pondera que somente a partir da conscientização e da reflexão sobre as estruturas da sociedades e valores dados como habitus, será possível uma desconexão com a apreensão de um modo em si, para uma reconstrução crítica.

Diana como amazona recém-chegada à Europa, demonstra respeito àquela nova cultura e costumes, mas isso não a impossibilitou de perceber as desigualdades vigentes para criticar, como no diálogo supracitado com Etta Candy. Diana tem voz, e ensina as mulheres a exercerem suas vozes, mesmo em cenários androcêntricos de quase silêncio feminino. Diana representa e desempenha no universo de super-heróis o protagonismo feminino. Sobretudo, uma voz feminina no ápice de uma avassaladora guerra, pautando o viés do amor. Trata-se de uma protagonismo peculiar, estrondoso e provocativo. Nesse sentido ponderam Weschenfelder e Colling

A mulher sempre teve seu papel nas histórias em quadrinhos de super-heróis, primeiramente como coadjuvante, sendo o objeto das maquinações dos vilões, e após um tempo, com as marchas dos movimentos feministas e os movimentos pelos direitos humanos, como papel principal, sendo a super-heroína das histórias. (WESCHENFELDER e COLLING, 2011, p. 200).

Notamos no HQ1 e no filme 2017, a representação da emancipação feminina. Na emancipação proposta, um viés da justiça é por meio da igualdade entre gêneros. Outrossim, há um lembrete e verdade sendo aventados - a humanidade é feita por semelhantes. Logo, distinções e preconceitos não devem ser favorecidos. Diana 
anda com pessoas de etnias variadas e por todas elas, se propõe a vencer a guerra.

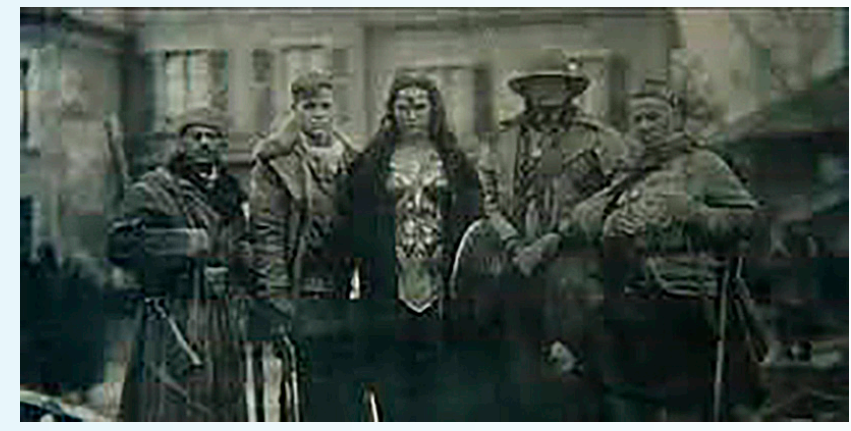

Imagem 6: Mulher Maravilha e amigos

Fonte: DC Comics- Filme 2017

$\mathrm{Na}$ foto, vemos a representação da diversidade multicultural e étnica - oriente médio, anglo-saxão, amazona greco-romana, índio americano e escocês. Isso sugere a união dos povos contra a guerra. Ao romper com essas normatizações e segregações sociais, Diana se nomeia como alguém que assume uma tarefa libertadora, comprometida com a dignidade humana e com a igualdade de direitos. Diana em determinada cena afirma: "Se tiver de interferir com um sistema acomodado e antiquado para ajudar apenas uma mulher, um homem ou uma criança... Aceito de bom grado as consequências."

Em uma cena do filme na qual Diana resolve ir para a linha de frente, Trevor movido por sentimentos múltiplos diz à Diana: "Eu não posso deixar você fazer isso". Diana imediatamente responde: "O que eu faço não depende de você". Há na fala de Diana uma mensagem de liberdade feminina que rejeita submissões, mas também de comprometimento com sua missão de salvar o mundo, que estava acima de sua autopreservação. O amor pela humanidade e seu compromisso, sobrepujou o amor eros por Trevor. 
Lewis (2017, p. 125) ao falar sobre o amor eros explicou "quero dizer, é claro, aquele estado emocional que chamamos de estar apaixonado, ou se preferir, estar amando."

Diana com sua armadura segue firme no objetivo de vencer Ares. Em Ef. 6.14, há um encorajamento para que a humanidade se mantenha firme, cingida com o cinto da verdade e com a couraça da justiça. Ela luta pelas vítimas da guerra e pelo fim da guerra - e verdade e pela justiça. Por isso, afirma "Eu vou lutar, por todos aqueles que não podem lutar por eles mesmos." Notemos que a afirmativa não é direcionada a um grupo, ao contrário é igualitário e inclusivo, porque trata dos oprimidos, fragilizados, segregados, todos como parte da mesma humanidade a ser protegida por ela. Há nessa abordagem a suscitação de igualdade e justiça. Aliás, o preceito de justiça também é encontrado na cultura grego-romana ${ }^{11}$, que é a origem da heroína.

Pensando nisso, consideramos como oportuno trazer o conceito de justiça na perspectiva aristotélica. "[...] a justiça é a base da sociedade; sua aplicação assegura a ordem na comunidade social, por ser o meio de determinar o que é justo. Aristóteles (1997, p.1253). Nessa esteira, aduz Oliveira

A evocação do conceito de cidadão, proposto por Aristóteles e defendido na Grécia Antiga, pois nesse contexto nem todos são considerados cidadãos. No plano coletivo, a justiça visa ao equilíbrio e à equidade na comunidade política. A virtude da justiça não só contribui para a felicidade interior do homem como também para a sua realização máxima, ou seja, sua vida pública. (Oliveira, 2009, p. 17).

Se as pessoas são a base da sociedade, devemos pensar ne-

11. Embora o conceito de justiça também perpasse outros sociedades e culturas, destacamos a greco-romana devido à origem da heroína. 
las de maneira a não favorecer desigualdades e segregações, é o que Diana defende ao dizer "lutar por todos". De acordo com a fala de Diana, não deve haver distinções entre humanos, e se houver, que seja em prol dos que não podem se defender. A proposta é compaixão, os mais fortes cuidam dos mais fracos. Ainda na perspectiva aristotélica, a justiça é posta como uma virtude que se volta para o outro. Por isso, na justiça, teremos um importante componente ético-jurídico de igualdade e serviço humano. Sendo assim, a justiça não se realiza na omissão ou na ação violadora contra o outro, pois tais atos são injustos ao negar a face do outro como aduz Levinas (2014). A justiça é como o sol que vem, e alcança a todos igualmente com alteridade e no amor.
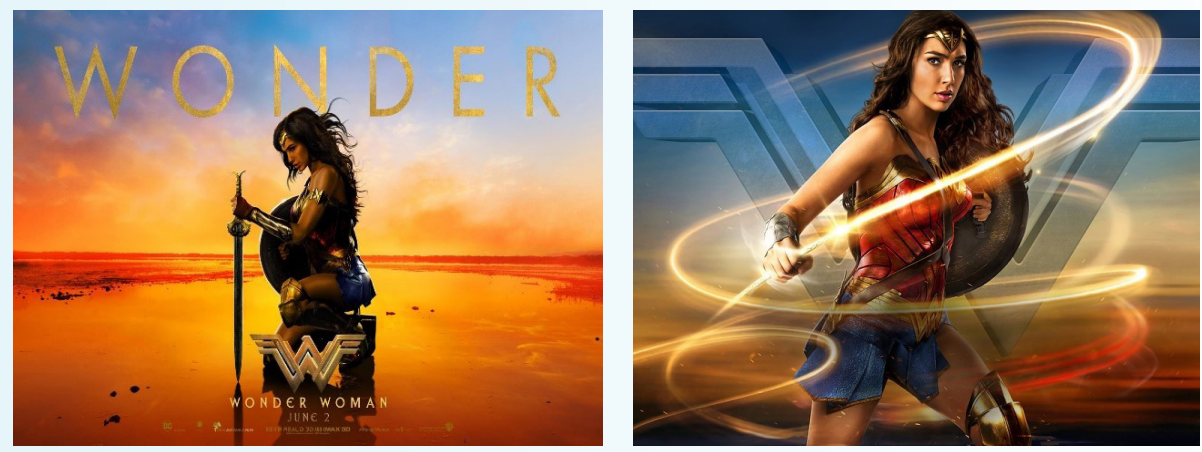

Imagem 7: Mulher Maravilha, justiça e verdade Fonte: DC Comics - Filme 2017

Justiça, amor e alteridade são premissas éticas, mas também se entremeiam aos preceitos teológicos cristãos, por exemplo. Pensando em termos teológicos, Santos (2010, p. 27) pondera que "a justiça divina não é, todavia, distribuição equânime de benefícios; Deus é justo porque protege seu povo fraco, inocente, vítima de adversários ímpios e age assim por sua fidelidade à aliança." De joelhos, porque não é possível praticar a justiça distante da 
humildade e compaixão, Diana vestida em sua armadura é alcançada pelo o sol que brilha, uma recordação de Malaquias 4.2 ${ }^{12}$. A justiça está sempre a serviço e se inclina na busca da verdade, com sua espada arriada, ajuíza paz. Em um estudo sobre os símbolos da justiça, sobretudo sobre a espada, Ost ensina que

A espada, que significa a violência inerente a uma solução que "fatia" um debate e, se for o caso, impõe uma sanção (e representa especialmente, como tal, um dos aspectos do monopólio da violência legítima" que Max Weber atribuía à figura do Estado). (OST, 2017, o. 116).

Notamos que, a espada remonta a deusa da sabedoria Atena "pela lança de Atena", que propõe a liberdade da ignorância e por isso, propicia a paz. Aliás, a paz teria sido um presente dessa deusa à humanidade, como cita o HQ1. O ramo de oliveira, é o símbolo de Atena por associar a paz à prosperidade. De fato, a história nos mostra que a guerra traz consigo o caos, a morte e a miséria. Estes elementos nos fazem concluir que a violência e a guerra são frutos da ignorância. Muito embora, os que promovem guerra e violência constantemente tentem legitimá-las a partir de falácias étnicas, raciais, econômicas, políticas, religiosas, dentre outras. Arendt (1994, p. 07) alerta para a violência que busca se mostrar como algo corriqueiro, quando é um equívoco que não deve ser ignorado.

"[...] isso mostra até que ponto se tornou a violência e a sua arbitrariedade como fatos corriqueiros e foram, portanto, negligenciadas. Ninguém questiona ou examina aquilo que é óbvio para todos. [...] A violência é instrumento."

12. Ml. 4.2: Mas para vós, os que temeis o meu nome, nascerá o sol da justiça, e cura trará nas suas asas; e saireis e saltareis como bezerros da estrebaria. 
A violência não é óbvia para Diana, ao contrário, é caos ilegítimo, que precisa ser encerrado. A motivação de Ares na guerra perpassa o poder e o domínio e para isso, utiliza da violência como instrumento. A motivação de Diana é a paz e decorre do amor. Nessas circunstâncias, Ricoeur (1995, p. 190) ensina que "parece que o horizonte do ato de julgar é, em última análise, mais do que a segurança, é a paz social." Essa busca determinada pela paz social é evidente no filme, aliás, é o objetivo da Mulher Maravilha.

Diana (2017) pondera "se a perda o faz duvidar de sua crença na justiça, então você nunca acreditou na justiça." No caminho proposto pela justiça, há intrinsecamente uma busca pela verdade (Jo. 8.32), cujo objetivo é a paz. Diana segue o caminho do amor na busca da justiça. Diana reconhece que "como reagimos ao ser confrontados com a verdade é mais difícil do que pensamos." Tolstói (2011), dirá que, "não se trata de permanecer passivo frente ao mal ou à violência, mas de responder a ela pela não-violência: a bondade, a mansidão e a caridade." A Mulher Maravilha segue determinada a ajudar a humanidade na luta contra o Ares que se revela na história e em nós.

\section{O deus Ares: a obsessão pela guerra e pelo poder}

Vamos ver que tipo de desusa você é. Você me ajudará a destruí-los Diana, ou morrerá. (ARES, 2017).

Na mitologia grega, Ares era o deus da guerra, filho de Zeus com Hera. Na mitologia da Mulher Maravilha, Ares é o filho de Zeus e Hera que enlouqueceu e buscou destruir os demais deuses, para dominar soberano. Ares era um deus violento e Diana o conhecia, o que é evidenciado pela associação imediata da guerra na Terra 
com Ares. Ao revelar-se em forma humana, forja sua armadura do fogo gerado pelo caos e morte. Para cumprir seus objetivos o instrumento sempre utilizado é a violência. Arendt pondera que (1994, p. 32) "de fato, a violência pode ser vista como um instrumento. A violência é, por sua própria natureza, instrumental, como todos os meios, está sempre à procura de orientação e de justificativas pelo fim que busca." Nesse aspecto, "a violência como instrumento é frequentemente utilizada para fins de dominação e para o exercício de formas de poder."

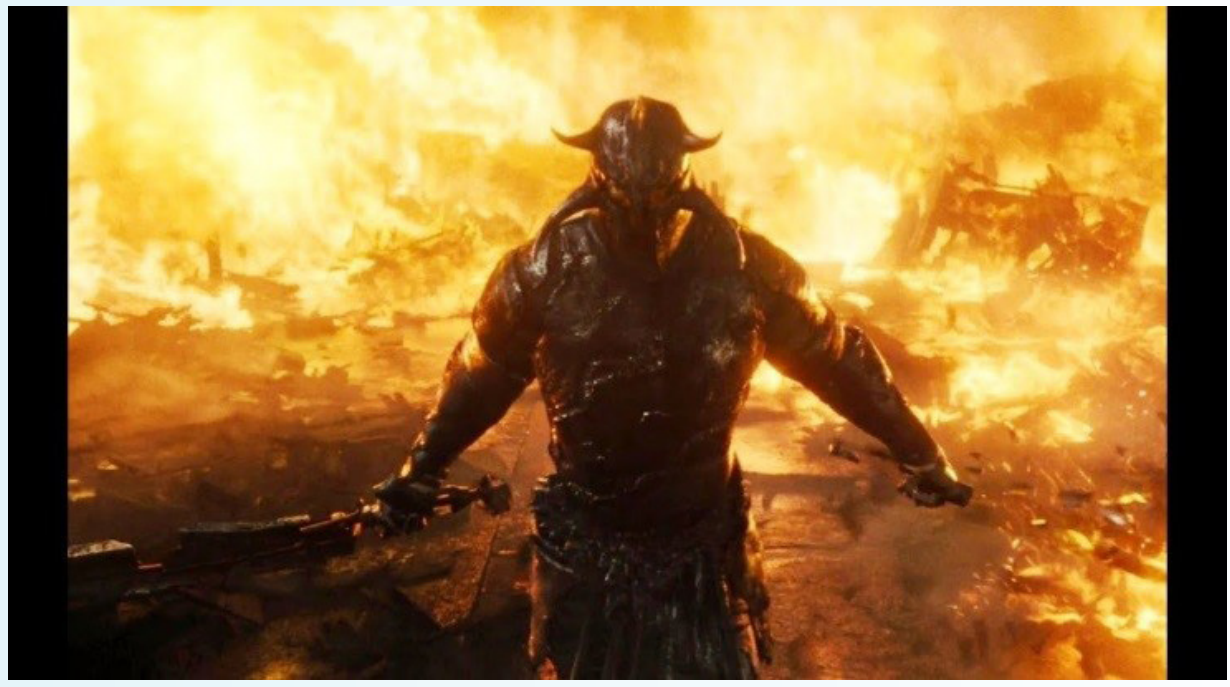

Imagem 8: Ares com sua armadura forjada de material bélico e fogo do caos Fonte: DC Comics - Filme 2017

No dicionário de Ética e Filosofia Moral, organizado por CantoSperber, violência é

1. ação cometida ou omitida, realizada como parte de um método de luta, que implica o assassinato de uma ou várias pessoas ou que supões que se inflige a esse padecimentos ou lesões físicas ou psíquicas; 2 . De modo intencional; 3. Contra sua vontade. [...] O infligir violência por meio físico é tão violento quanto infligir 
danos psíquicos é também ação moralmente negativa ou profundamente injusta. (CANTO-SPERBER, 2003, p.762).

Na mesma esteira, Chauí (2017, p. 254) que "a violência se opõe à ética porque trata seres racionais e sensíveis, dotados de linguagem e de liberdade, como se fossem coisas, isto é, irracionais, insensíveis, mudos, inertes." A postura de Ares revela a ânsia pelo padecimento alheio. A mitologia grega retrata Ares como um deus que não vivia com os demais deuses no Monte Olimpo, ao contrário, ele cria o seu próprio reino, chamado Areópago - Colina de Ares, pois não conseguia viver em harmonia com os demais. Ares, que costumeiramente era retratado na mitologia irado, queria sempre dominar, violar, sucumbir.

$\mathrm{Na}$ terra, este deus utilizava dos desejos humanos de dominação, violência, vingança, cobiça, realizando assim seu objetivo via caos, violência, crueldade, para então desencadear a guerra, independentemente da causa, motivações e partes envolvidas. Este era o jogo de uma eterna batalha alimentada por Ares, que o alimentava em termos de poder. Da mesma maneira, os humanos envolvidos no desencadear da guerra, em não raras circunstâncias estão imbuídos de desejos próprios e usam de manipulação para alcançar o fim desejado com uma pseudo-legitimação. Se é dessa maneira, a história da humanidade tem página escritas sob os auspicio de Ares. Destacamos que o General Ludendorff, que foi retratado como um vilão no filme da DC 2017, de fato existiu no cenário da I Guerra, e possuía o mesmo nome. No filme, o general usa o poder bélico para fins pessoais. Essa seria a face bélica de Ares. 


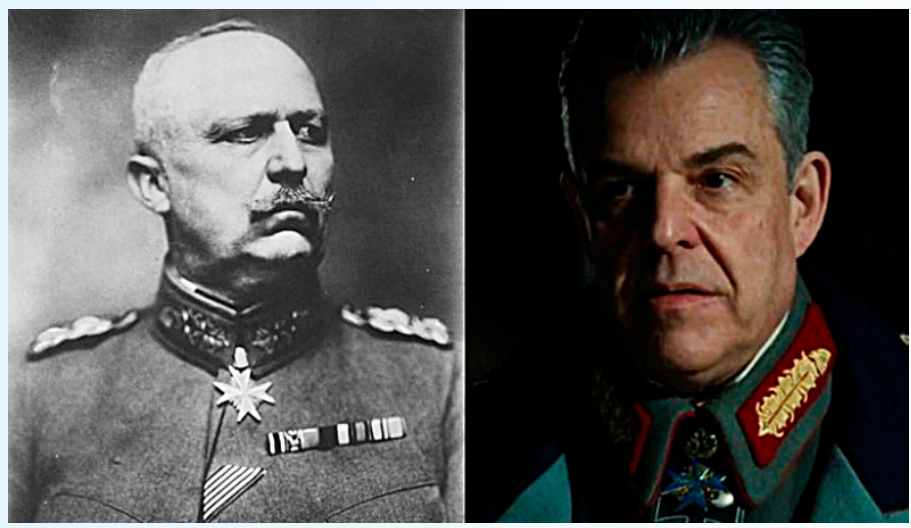

Imagem 9: General Ludendorff à esquerda e o personagem do filme Mulher Maravilha (2017) à direita.

Fonte: Revista Galileu

A face de Ares se mostra também por meio da ciência e do conhecimento desprovido de ética, como meio de manipulação, objetivando igualmente poder e dominação. Essa figura é representada pela vilã Dra. Veneno, que no filme 2017 é retratada como uma mulher com um passado de muito sofrimento, que decide pela maldade e vingança em detrimento ao perdão e superação. A inteligência e o conhecimento são seus instrumentos de dominação e poder. Bourdieu (2002) diz que o conhecimento, a informação, as habilidades são parte do capital cultural, pois, o conhecimento é poder.

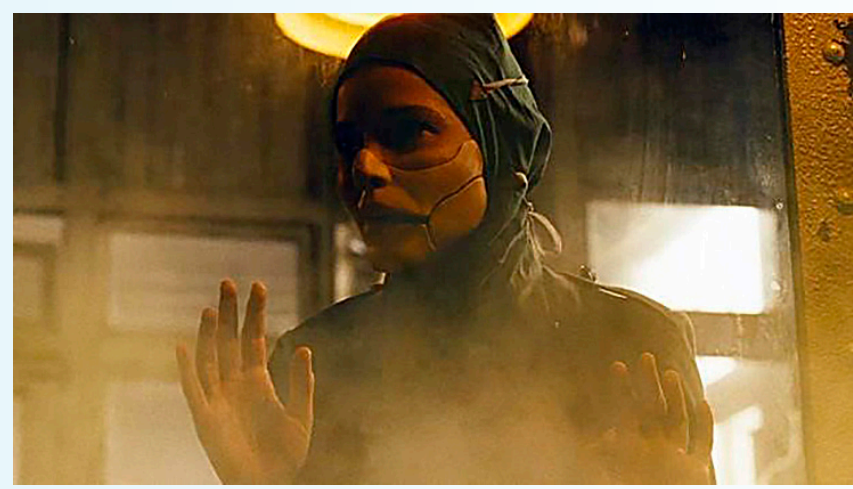

Imagem 10: Personagem Dra. Veneno do filme Mulher Maravilha (2017) Fonte: DC Comics - Filme 2017 
O sofrimento envenenou a alma da Dra. Veneno, que deseja destilar a mesma dor nos outros. Entende a vilã que o sofrimento do outro é o remédio para sua dor. Focada nisso, transforma seu conhecimento em ignorância e desenvolve um potente veneno para dizimar a Europa. No filme 2017, a Dra. Veneno usa armas químicas para gerar o caos coletivo.

Na perspectiva de Ares, o sofrimento humano também o alimenta, pois é oriundo de uma guerra de conotação simbólica, da mesma maneira como temos a violência simbólica. Sobre a violência simbólica, Bourdieu (2002) nos alerta para a sutileza da violência simbólica que se entremeia nas relações e por isso, nem sempre é notada, embora danosa, pois é um instrumento sútil.

Ritz (2018) o poder quando é associado à violência, gera caos e não a paz, porque se manifesta via dominação e desigualdades, por conseguinte, contra a dignidade humana. Ao contrário, Diana é posta como a princesa amazona que se deixa afetar pela dor das pessoas, que se doa para buscar a paz e seu poder é utilizado para libertar.

\section{A Mulher Maravilha e o poder do amor que gera paz}

\section{É sobre o que você acredita. Eu acredito no amor e apenas} o amor pode salvar o mundo. (DIANA, 2017).

Ao se deparar com soldados feridos, pessoas desabrigadas e uma mãe desesperada com seu bebê, Diana se sente tocada e compelida a agir. Esse senso de justiça e de alteridade, pode ser considerado como resultado das obras do amor. Kierkegaard (2011) considera o amor ao próximo como aquele que se oriunda de Deus que seria o verdadeiro amor cristão. Aliás, a partir de Mt. 22.39, Kierkegaard (2011, p. 32), relembra as Escrituras "o segun- 
do mandamento é semelhante a esse, amarás o teu próximo como a ti mesmo".

A mesma atitude é demonstrada por Diana quando em meio a batalha percebe soldados atirando com armas e canhões contra pessoas civis inocentes em uma praça. Após uma olhadela, percebe que o atirador está escondido na torre da Igreja situada na mesma praça, entorno da qual, a cidade se estruturou. Na cena, todos estão acuados com as rajadas de tiros. Diana então se ergue, olha para a Igreja corre, se apoia nos seus amigos humanos e salta. Com um soco, Diana atinge a torre da Igreja que imediatamente começa a se despedaçar, a ruir. A cena muda o ângulo de filmagem e revela uma Igreja grande e imponente como centro de um povoado pequeno e de casas humildes que a circundam.

A princípio, todos observam o feito em silêncio, com ar de pesar pela torre da igreja, até que percebem que estão seguros. Percebem também que entre a Igreja e a vida das pessoas, Diana escolhe as pessoas. A torre construída cai, mas Igreja permanece de pé e as pessoas vivem. Em Atos 7.48, temos a existência divina para além de construções humanas: "Todavia, o Altíssimo não habita em casas feitas por homens. Como diz o profeta." Diana é ovacionada. Nesse percurso, Diana conta com Steve Trevor e mais três homens que juntamente, pelejam pelo fim da guerra.

$\mathrm{Na}$ perspectiva kierkegaardiana, amar é um dever mais que ético, e no aspecto teológico, é dever cristão. A questão é, entre a torre da igreja e pessoas pobres, qual dessas alcançam mais profundamente o nosso coração? $\mathrm{O}$ amor deve reverberar em nossos semelhantes, e não em construções humanas. Entre a torre e as pessoas, Diana escolheu as pessoas - escolha de alguém que ama e entende o mandamento do amor. De acordo com Kierkegaard 
(2011, p. 247) "O amor é a fonte de todas as coisas, e no sentido espiritual, o amor é o fundamento mais profundo da vida espiritual. Em cada ser humano em que há amor, está implantada no sentido espiritual a fundação."

A Mulher Maravilha é confrontada com a morte de Steve Trevor, que se doa pela humanidade, em abnegação na busca do bem comum - ato de amor. As circunstâncias da morte no lembram da perspectiva de Schopenhauer (2006), a morte como acontecimento, como parte do ciclo constante, parte importante para o fluir do ciclo. É preciso morrer para que a vida continue e por isso, Steve Trevor deixa a mensagem, é preciso morrer para que os demais vivam. Lobato (2017) numa leitura schopenhaueriana diz que o pôr do sol em um lugar, é o nascer do sol em outro. A morte, além da guerra, são verdades duras, com as quais Diana é confrontada.

No momento da morte de Steve, a dor faz com que Diana sinta muitas emoções. Num momento inicial de ira pela perda, Ares vê a oportunidade de ter Diana como sua aliada e diz: "Olha para esse mundo Diana, a espécie humana fez tudo isso, não eu. Eles são horríveis, cheios de ódio, fracos, assim como Trevor. Ele fugiu e deixou você sozinha" A cena de fundo é de caos, a guerra. Diana reflete e afirma: "os humanos são tudo isso, mas não apenas isso. [...] não importa o que eles merecem, mas no que acreditamos. $\mathrm{E}$ eu, acredito no amor." Diana age diferente da Dra. Veneno, diante da dor e perda. É possível escolher o amor, mesmo em meio ao caos externo ou interno.

Diana ativa seus braceletes, os quais, segundo HQ1 deveriam lembrá-la de não se submeter ao domínio dos homens. Ela não se submete a Ares ou ao ódio. Seus braceletes lançam raios na direção de Ares, uma aparente referência à Zeus. 


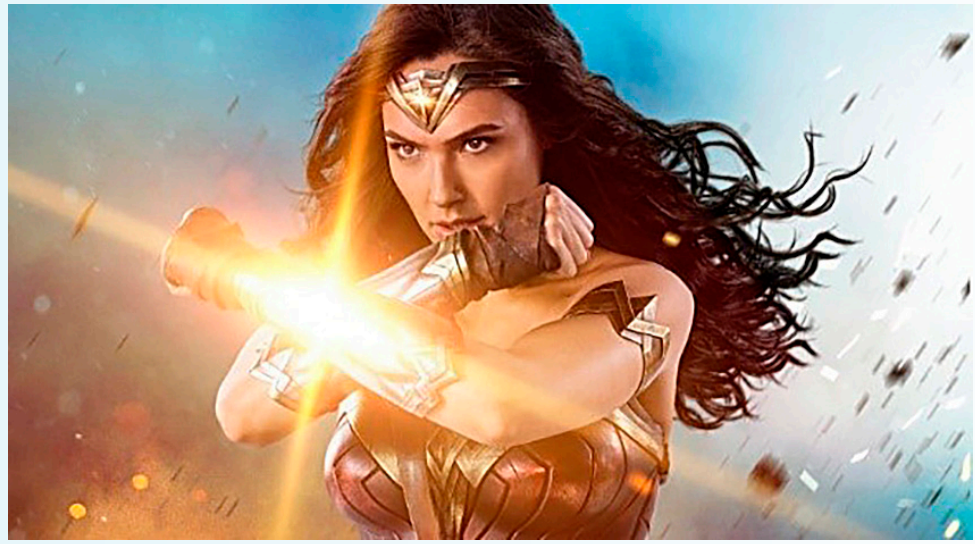

Imagem II : Braceletes da submissão ativados

Fonte: DC Comics - Filme 2017

Ao se elevar aos céus em forma de cruz rodeada por raios e luz, há uma aparente ascendência transcendente pelo amor à humanidade. Diana emana energia luminosa em Ares, que é reduzido a um ponto de luz no chão.

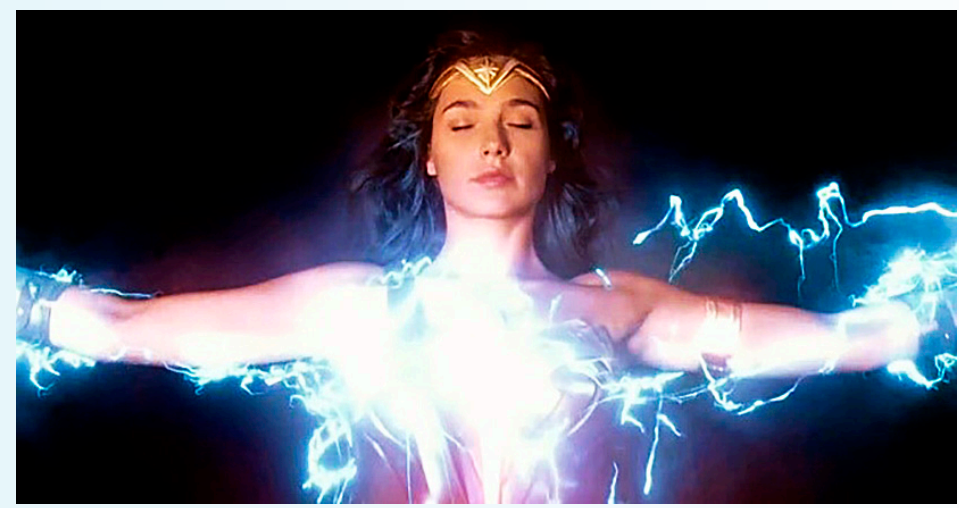

Imagem 12: 0 poder do amor

Fonte: Filme DC Comics 2017

A amazona exala alteridade que se entrelaça com amor. Segundo Emmanuel Lévinas (2000), a violência encontra sua condição de possibilidade na negação do outro, enquanto a alteridade implica na negação de qualquer violência, pois busca o encon- 
tro com o outro. Nesse mesmo sentido, explicam Flávio Senra e Fabiano Victor Campos (2014, p. 324): "por isso, Lévinas pensa Deus a partir da relação humana de encontro com o outro, na qual o sujeito é eleito à responsabilidade por outrem."

Esse encontro com outro é viabilizado pelo esteio do amor. Diana escolheu, acreditou e praticou o amor, e nesse ato residiu o seu maior poder. Especialmente por amar e ensinar que devemos acreditar no poder do amor, ela é a Mulher Maravilha.

\section{Conclusão}

Nesse artigo apresentamos um pouco da história da Mulher Maravilha narrada no HQ1, que revela não apenas a origem greco-romana da amazona, mas também seus preceitos éticos de justiça, alteridade e amor. Há uma polaridade entre Marte e Afrodite que enseja a discussão mitológica sobre a guerra e o amor. Aliás, essas são temáticas contemporâneas.

Outrossim, o HQ1 apresenta uma heroína, num cenário com predominância de heróis. A Mulher Maravilha que rompe com os padrões vigentes da época, não apenas nos HQs, como também na sociedade vigente, pois questiona a hegemonia masculina. Além disso, aborda a dominação mediante o exercício do poder, que em não raras circunstâncias, utiliza a violência como instrumento. Essa abordagem num contexto de guerra é vanguardista e tem forte conotação social e política.

Destarte, tanto no HQ1 e no filme (2017), somos convidados a pensar sobre a violência, a guerra, as relações de gênero que favorecem a submissão das mulheres aos homens, mas também, sobre a alteridade, a justiça e o amor. Noutro giro, esses preceitos 
fomentam também a reflexão teológica.

Por isso, concluímos que tanto o HQ1, quanto o filme 2017 da DC Comics, estão repletos de questões mitológicas, históricas, sociais, políticas e também teológicas. Estes aspectos nos conduzem a uma reflexão sobre a teoliterária a partir dessa forma de arte, que embora ficcional, favorece o pensar a partir do momento histórico vivido e dos conflitos éticos, morais, sociais e políticos, os quais são humanos. A síntese proposta no HQ e no filme 2017 é a busca da paz e a crença no poder do amor.

\section{REFERÊNCIAS}

ARENDT, Hannah. Sobre a violência. Tradução de André Duarte. Rio de Janeiro: Relume-Dumará, 1994.

ARISTOTÉLES. Política. Tradução de Mário da Gama Kury. 3a ed. Brasília: Editora Universidade de Brasília, 1997.

BOURDIEU, Pierre. A economia de trocas simbólicas. 6. ed. São Paulo: Perspectiva, 2007.

BOURDIEU, Pierre. O poder simbólico. 5. ed. Rio de Janeiro: BetrandBrasil, 2002. BURKHARDT, H.; GRÜNZWEIG, F. Giustizia. In: Grande Enciclopédia Illustrata della Bibbia. Torino: Piemme, 1997. v. 2, p. 133.

CALDAS, Carlos (Org.). Teologia Nerd. São Paulo: Garimpo Editorial, 2015.

CALDAS, Carlos. Das HQ's como discurso teológico: análise de x-men - deus ama, o homem mata, de Chris Claremont na perspectiva da soterologia de Paul Tillich. Teoliterária. V.7, n. 14, p. 70-90, 2017.

CALDAS, Carlos. Religião e HQ's: análise de Demolifor: diabbo da guarda, de Kevin Smith e oe Quesada. Numem. V.21, N. 1, p. 211-222, 2018.

CAMPOS, Fabiano Victor de Oliveira. O Ser e o Outro do Ser: a questão de Deus em Emmanuel Lévinas. 2016, 501 f. Tese (Doutorado), Programa de Pós-Graduação do Departamento de Ciências da Religião, Universidade Federal de Juiz de Fora, Juiz de Fora, 2016. Disponível em: <https://repositorio.uffifbr>. Acesso em: 22 jan. 2018.

CHAUÍ, Marilena. Sobre a violência. In: ITOKAZU, Ericka Marie; CHAUI-BERLINCK, Luciana. (Orgs.). Belo Horizonte: Autêntica, 2017. 
DC Comisc, HQ1. Edição de verão, EUA.

DC Comics, Mulher Maravilha, EUA: 2017.

GROSSMANN, Judith. Temas de teoria da literatura. São Paulo: Ática, 1982.

IGBE. Estatística de Gênero no Brasil. 2018. Disponível em: https://biblioteca. ibge.gov.br/visualizacao/livros/liv101551_informativo.pdf. Acesso em: 01. maio. 2018.

KIERKEGAARD, Soren. A. As obras do amor. São Paulo: Vozes, 3ạ ed., 2008 [1947]. KIERKEGAARD, Soren. A. Temor e Tremor. São Paulo: Martin Claret, 2008 [1849].

LEWIS, C. S. Os quatro amores. Tradução Estevan Kirschner. Rio de Janeiro: Thomas Nelson, 2017.

LOBATO, Milene Dayane Paes. Revista Saberes. v.1, n.17, 55-66, 2017.

MARSTON. William Moulton Marston. Don't laugh at comics. CBDL Org. Disponível em: http://cbldf.org/2012/10/tales-from-the-code-whatever-happened-to-the-amazing-amazon-wonder-woman-bound-bycensorship/. Acesso em: 02 de maio. 2019.

MORRIS, Matt e MORRIS, Tom (Orgs.). Super-heróis e a filosofia. Verdade, justiça e o caminho socrático. São Paulo: Madras, 2009.

OLIVEIRA, Andréa Coutinho Pessoa de. A virtude da justiça no pensamento aristotélico. 106f. 2009. Universidade Estadual do Ceará, Centro de Humanidades.

OST, François. A justiça, suas alternativas e seus símbolos. Vingar, perdoar ou julgar? Variações literárias. Revista de Estudos Constitucionais, Hermenêutica e Teoria do Direito (RECHTD), 6(2):116-128, 2014.

REBLIN, luri Andreas. Perspectivas hermenêuticas acerca da representação religiosa nas histórias em quadrinhos. Nona Arte: Revista Brasileira de Pesquisas em Histórias em Quadrinhos, v. 2, p. 37-52, 2013.

REBLIN, luri Andreas. Superaventura: da narratividade e sua expressividade à sua potencialidade teológica. Tese de Doutorado. 257 f. 2012. Faculdade de Teologia São Leopoldo EST.

REBLIN, luri Andreas, BRAGA, Amaro Xavier Junior (Orgs). Religiosidades nas histórias em quadrinhos. Leopoldina: ASPAS, 2015.

RICOEUR, Paul. L'acte de juger. In: P. RICOEUR, Le juste. Paris, Esprit, 1995.

SENRA, Flávio; CAMPOS, Fabiano Victor de Oliveira. Senso Religioso Contemporâneo e os Sem Religião: uma provocação a partir de Emmanuel Lévinas. Revista Caminhos - Estudos de Ciências da Religião, Goiás, v. 12, n.2, p. 312- 331, 2014. 
SCOTT, Joan W. Entrevista: Joan Scott. Entrevista concedida a Fernanda Lemos.

Revista Mandrágora, São Paulo: v. 19, p. 161 -164, 2013. Disponível em: <https://www.metodista.br>. Acesso em 06 mar. 2018.

SCOTT, Joan W. Gênero: uma categoria útil para análise histórica. Tradução: Christine Rufino Debat e Maria Betânia Ávila. New York: Columbia University Press, 1989. Disponível em: <https:www//edisciplinas.usp. br>. Acesso em 27 jan. 2018

SHOPENHAUER, Arthur. Da morte, metafísica do amor, Do Sofrimento do Mundo. Tradução Pietro Nassetti. São Paulo: Martin Claret, 2006.

TOLSTOI, Leon. O reino de Deus está em vós. São Paulo: Bestbolso, 2011.

VIANA, Nildo. Heróis e super-heróis no mundo dos quadrinhos. Rio de Janeiro: Achiamé, 2005.

WESCHENFELDER, Gelson Vanderlei ; Colling, Ana Maria. Histórias em quadrinhos de super-heroínas: do movimento feminista às questões de gênero. INTERthesis: Revista Internacional Interdisciplinar, 2011, Vol.8(1), pp.200-218 